\title{
Recycled Plaster and Red Ceramic Waste Based Mortars
}

\author{
Sara B. Ferreira, Paulo C. Domingues, Silvete M. Soares, and Gladis Camarini
}

\begin{abstract}
Construction is the activity that generates more waste in the world. Even with international actions being done to seek sustainable solutions in human activities, few changes in the construction have been observed. In Brazil, measures are being taken to adapt the waste-generating activities to new environmental commitments. In 2002, a specific law on construction and demolition waste (CDW) (Res. 307 Law 12,305) was established to reduce its production or use its material and ensure its proper destination. In 2011 the plaster recycling was established by resolution 431 amending Res. 307. Thus, this work had the objective of using waste gypsum and red ceramic as building material. Different proportions were mixed and tests were made to evaluate their physical and mechanical performance and also optical microscopy. The results indicated that the mortar produced with recycled plaster and ceramic waste meets Brazilian technical standards as components of brick wall.
\end{abstract}

Index Terms-Ceramic waste, construction and demolition waste, plaster, recycling.

\section{INTRODUCTION}

Construction is the human activity that generates more waste in the world, whose raw material consumption represents about $50 \%$, in mass, of any residue generated on the planet. In the last century the use of construction materials increased by eight times, resulting in an annual production of 60 million tons. The consequences go beyond the reduction of raw materials, where part of it is not renewable, but causes environmental impacts such as the destruction of biodiversity, air and water pollution [1].

In 2000, 189 countries signed the Millennium Development Goals (MDG), an important document in which they compromise to seek strategies to ensure environmental sustainability, strengthening the agreement of the Kyoto Protocol. However, since the agreement signed, few studies of the construction area have been directly related to sustainability, such as the environmental issue of building materials. The proportion of scientific publications in the construction area in which the object of study was related to sustainability is of around $10 \%$ of all publications released in

Manuscript received April 5, 2014; revised June 14, 2014. This work was supported in part by the Laboratory of Binder and Wastes of the School of Civil Engineering, Architecture and Urban Design - UNICAMP, by the National Counsel of Technological and Scientific Development - CNPq and by the Instituto Federal de Educação, Ciência e Tecnologia do Sul de Minas GeraisIFSULDEMINAS

Sara B. Ferreira, Paulo C. Domingues, and Silvete M. Soares are with Federal Institute of Science and Technology, Poços de Caldas, MG, Brazil (e-mail: sara.ferreira@ifsuldeminas.edu.br, paulo.domingues@ifsuldeminas.edu.br, silvetemari@yahoo.com.br).

Gladis Camarini is with the School of Civil Engineering and Urban Design at University of Campinas, UNICAMP. Campinas, São Paulo, Brazil, Av. Albert Einstein, 951, POBox 6021, CEP: 13083-852, Campinas, SP (e-mail: gcamarini@gmail.com, camarini@fec.unicamp.br). one decade by Elsevier magazine. However, when it comes to studies regarding construction and demolition wastes $(\mathrm{CDW})$, the proportion is even smaller, around $0.2 \%$ [1]. Even with the environmental and economical advantages (CDW activities generated an income of 744 million Euros in 2010), the percentage of recycling of CDW in Europe is about $47 \%$. The low activities related to the use of the CDW in the market are partially due to the profile of the civil construction companies which behave in a resistant way towards new technologies, even thought if they are beneficial to the environment. It may take from 10 to 20 years to develop a new composite until it is well accepted. It is necessary to create mechanisms so that research in the area of the CDW is aligned to their market viability, reducing time and costs by the companies [2]. An alternative would be to stimulate partnerships between companies and research centers, aligning the goals of research on issues of importance to their large-scale production. Another important action is related to updates and revisions of technical standards. Without proper monitoring of standardization with the innovations of construction materials, its feasibility remains committed [1]. And, finally, other attitudes could also take part, as stimuli to the consumption of materials and more environmentally responsible construction processes, such as mandatory environmental seals, reductions in taxes and government fees for anyone who manufactures more sustainable products and for who uses them [1].

In Brazil, the context of environmental concerns and recycling in the construction sector are similar. In 2002, it was appended to Law 6,938 of 1981, which deals with National Environmental Council (CONAMA) [3], the theme of solid wastes, including CDW. In 2010, the Law 12,305 establishes the National Solid Waste Policy (PNRS), making clear the responsibility of waste management taken by the public administrations, as well as establishing deadlines for the implementation of solid waste management. In 2002, the 307 CONAMA resolution specifically addresses the CDW establishing deadlines for the local governments to deploy their policies for appropriate disposal. With the change of 307 by 448, in 2012, the deadline was extended for 2014 . However, it can be observed that little or no change is seen in the Brazilian municipalities. The priority for such policy is the reduction of the $\mathrm{CDW}$, followed by reuse and recycling, involving therefore, the generating companies: construction companies and all other activities in the construction industry.

The percentage of recycling of CDW in the country in 1999 was about $500 \mathrm{~kg} /$ inhab./year [4]. However, it represents a much larger volume today.

Brazil has 5,561 municipalities [5] and just around 310 recycling plants [4], which is insufficient for this number corresponds to a proportion of one plant for each 18 municipalities. If one considers the population of the country, in 2014 of approximately 170 million inhabitants and an 
output of $500 \mathrm{~kg}$ of CDW per capita per year, there are 85 million tons of CDW generated a year for only 310 recycling plants.

Despite the growth of CDW plants, about 10 new plants per year [4], more incentive is yet to be given, whether by public administrations or the private sector in the use of recycled materials, or in the supervision, triage and destination of the CDW's in the municipalities [4].

As a way of developing alternatives for a product that has qualities and applications in construction, we developed this study to use two construction wastes: gypsum waste and ceramic waste (residue from the production of ceramic tiles) to evaluate the performance of this composite as a construction material.

Gypsum plaster and ceramic are among the most present materials in the CDW. Their percentages in the residue composition vary greatly according to region of the country. Such variation is related to some factors like availability of materials, type of construction (new, demolition, remodeling), constructive processes, quality of workmanship, among others. In São Paulo, for example, ceramic material represents $33 \%$ of all CDW, while in Salvador-BA, it represents $15 \%$ [6]. Gypsum plaster also presents a great variety of CDW composition depending on the region of the country. In Campinas-SP, it represents $28 \%$ of all CDW. In São Carlos-SP, plaster represents $1 \%$ of CDW [7].

In the metropolitan region of São Paulo-SP, the estimate is about 120 thousand tons per year of construction gypsum plaster waste. The main sources of this waste are renderings $(88 \%)$, drywall $(8 \%)$ and components $(4 \%)$. Due to its advantages in relation to lower power consumption for its production and its relative simple recycling process, gypsum plaster has been an important material for recycling, mainly for representing a danger when wasted in locations without proper treatment. The material can contaminate the soil and groundwater.

Plaster is a material applied in various areas of a building such as finishing of walls, drywall, ceilings and masonry blocks. Its production is relatively simple and the process of reversibility of its reactions allows it to be used in the production of new materials. Its use was already known in $7,000 \mathrm{BC}$ in constructions in Turkey as mortar for floor [7].

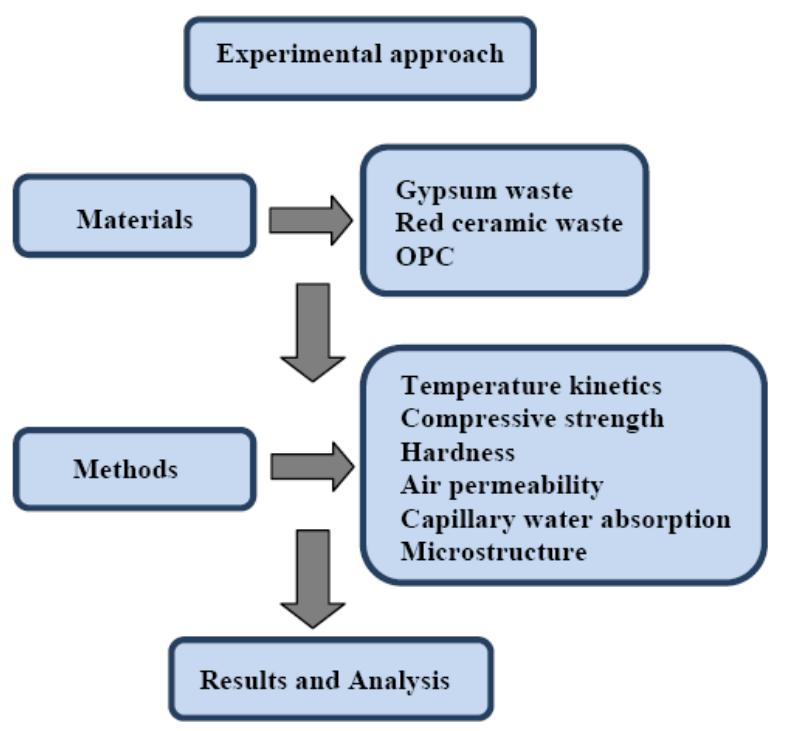

Fig. 1. Experimental approach
The use of gypsum waste and red ceramic waste meets the new aspirations and commitments of the construction activities both in environmental and economic terms. Applicability studies of waste materials in construction that meet regulatory requirements and user needs, stimulate a whole chain: exploitation of $\mathrm{CDW}$ and its consequent decrease in the environment, increase in the number of recycling plants, reducing consumption of raw materials for manufacturing of constructive elements, creation of jobs, among others [7].

The red ceramic (type of clay with higher iron content) represents an important market corresponding to $4.8 \%$ of the entire construction industry and consuming 10,300,000 tons of clay per month [8].

The objective of this study was to evaluate the physical and mechanical characteristics of composites produced with these residues (plaster and red ceramic) so it can be obtained a product with mechanical performance compatible with the requirements of standards for application in construction as brick walls [9].

The Fig. 1 shows the proposal approach of this experimental work.

\section{MATERIALS}

The materials used in this study were: construction plaster residue red ceramic waste and Portland cement.

\section{A. Gypsum Waste}

Gypsum waste was collected in construction sites and sent to the laboratory for recycling. The calcination was made at a temperature of $150^{\circ} \mathrm{C}$ for a period of 2 hours. The material was cooled and the recycled gypsum was used as a binder to produce the composite. Physical and mechanical properties were evaluated. The specific gravity, bulk unit weight and sieve analysis were determined according to the Brazilian Standards [10]. Fig. 2 shows the grading curve of the recycled gypsum plaster. The specific gravity was 2570 $\mathrm{kg} / \mathrm{m}^{3}$ and the bulk unit weight was $970 \mathrm{~kg} / \mathrm{m}^{3}$

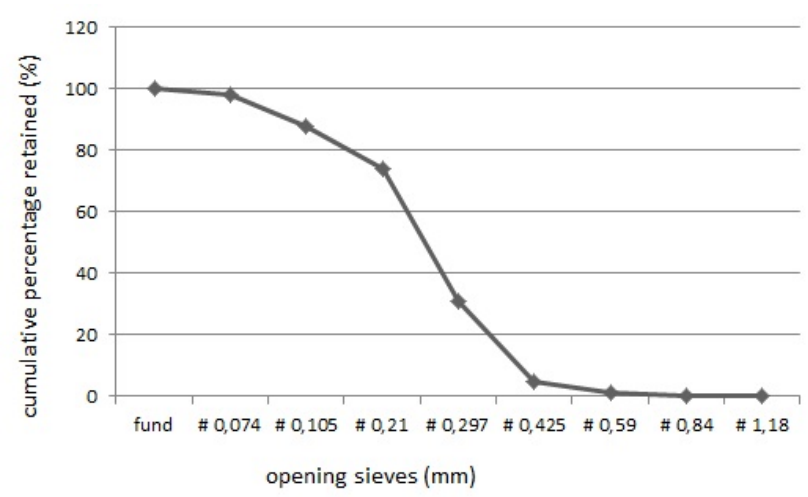

Fig. 2. Grading curve of the recycled gypsum plaster

\section{B. Red Ceramic Waste}

The red ceramic waste used was the residue from ceramic tiles [11]. This ceramic waste was supplied in grounded form. The specific gravity of the red ceramic was $2390 \mathrm{~kg} / \mathrm{m}^{3}$ and the bulk unit weight was $1313 \mathrm{~kg} / \mathrm{m}^{3}$. Fig. 3 presents the grading curve of red ceramic waste [10]. 


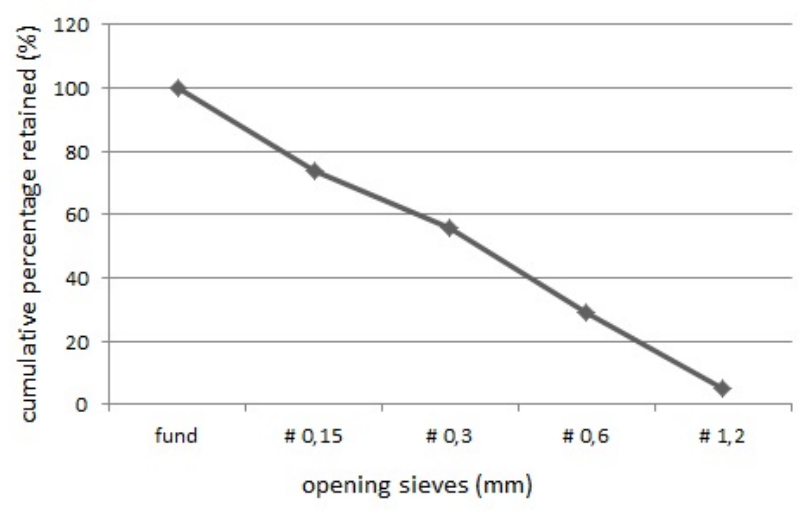

Fig. 3. Grading curve of the red ceramic waste.

\section{Portland Cement}

The cement used in this study was the High Initial Compressive Strength Portland Cement (CPV-ARI) with a specific gravity of $3100 \mathrm{Kg} / \mathrm{m}^{3}$.

\section{EXPERIMENTAL MIXTURES}

TABLE I: EXPERIMENTAL MIXTURES

\begin{tabular}{llcc}
\hline \hline Mixtures & Materials & $\begin{array}{c}\text { water/dry } \\
\text { materials } \\
\text { ratio }\end{array}$ & $\begin{array}{c}\text { Water/ } \\
\text { plaster } \\
\text { ratio }\end{array}$ \\
\hline GR & Recycled plaster (RP) & 0.8 & 0.8 \\
GS30 & RP + 30\% red ceramic waste (RC) & 0.8 & 1.14 \\
GS60 & RP $+60 \%$ RC & 0.8 & 2 \\
GS70 & RP $+70 \%$ RC & 0.8 & 2.66 \\
GSC60 & RP $+60 \%$ RC $+5 \%$ cement & 0.8 & 2 \\
GSC70 & $\mathrm{RP}+70 \% \mathrm{RC}+5 \%$ cement & 0.8 & 2.66 \\
\hline \hline
\end{tabular}

The mixtures were proposed so that the mortar could be easily molded and could gain the minimum mechanical performance within the relevant standards for the ceramic blocks for masonry walls [9]. So, we have adopted the proportions of materials with focus on water/dry materials ratio.

We used the water/dry materials ratio equal to 0.8 for a mortar with good workability, searching a more fluid one and, thus, filling the molds easily. Experimental mixtures are described in Table I.

In mixtures with $60 \%$ and $70 \%$ of red ceramic waste we added a small proportion of cement CPV-ARI ( $5 \%$ in mass of the quantity of dry material) to assess whether there was any contribution in terms of mechanical performance.

The dry materials (recycled gypsum and red ceramic) were mixed in advance and then added to the water. The mixture was manual until obtaining a homogeneous mixture. Specimens were molded and kept in the laboratory environment (temperature $23^{\circ} \mathrm{C}$ and relative humidity $60 \%$ ) until the date of the tests.

\section{METHODS}

The composite was tested in the fresh and hardened state. Temperature kinetics were determined in fresh state. In the hardened state, compressive strength, hardness, air permeability and capillary absorption were determined, and observations by optical microscopy.

\section{A. Temperature Kinetics}

In the fresh state, we evaluated the hydration of the experimental mixtures by means of temperature kinetics. In this test, we observed the variation of temperature of the mixture through the release of heat that indicates the beginning and end of setting.

The equipment is a semi-adiabatic calorimeter in which the studied mixtures are placed in order to isolate them from the external environment (Fig. 4). The temperature is measured by thermocouples inside the mixtures and thetemperature variations are recorded by a datalogger model Testo177-T4, with four reading channels [7].

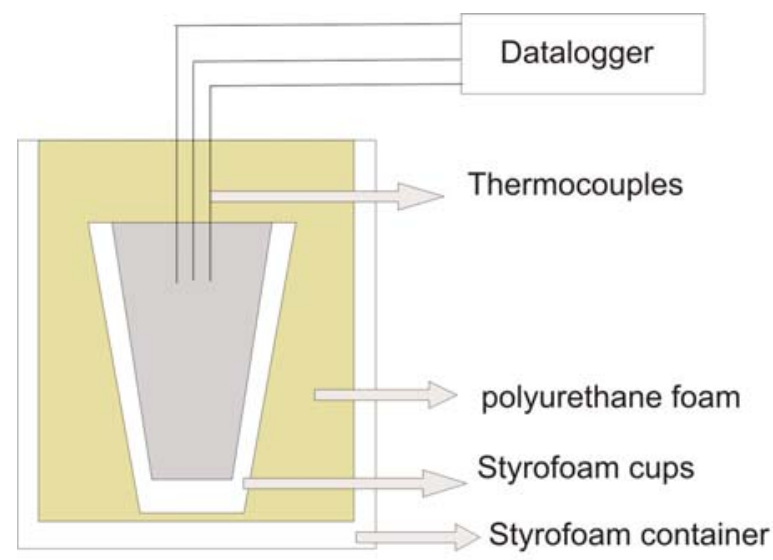

Fig. 4. Schematic illustration of the pseudo adiabatic calorimeter [8].

\section{B. Compressive Strength}

Compressive strength was determined on cubic specimens of $50 \mathrm{~mm}$ on edge. Six specimens were molded for each of the six mixtures, 3 specimens tested at 7 days and 3 at 28 days [12].

\section{Hardness}

The hardness was a measure of the depth of impression of a steel ball with $9 \mathrm{~mm}$ diameter, under a load of $500 \mathrm{~N}$, on three sides of a cubic specimen with $50 \mathrm{~mm}$ edge. For each series, the arithmetic average of the depths obtained from 3 specimens was taken [12]

\section{Microstructure of the Mixtures}

Mixtures were observed in an optical microscope registering images on surface fractures of cubic specimens remaining from the compressive strength test.

\section{E. Air Permeability Test}

The air permeability test of the specimen was carried out in a permeameter of constant load (Fig. 5) [13]. For this test, a cylindrical specimen of $50-\mathrm{mm}$ diameter by $100-\mathrm{mm}$ high was molded. Before the test, the specimen is dried in an oven, and the lateral surface was sealed. In the apparatus, the air is forced to flow through the specimen. Details of the test can be found in [14]-[15].

\section{F. Capillary Water Absorption}

Capillary water absorption was measured in $50-\mathrm{mm}$ diameter by $100-\mathrm{mm}$ high cylindrical specimens.

The specimens were placed in an oven for 24 hours at a temperature of $50{ }^{\circ} \mathrm{C}$. Then they were cooled and the lateral surface was sealed. Then they were placed in a vessel 
containing water and supported on a metallic tray so that only $10 \mathrm{~mm}$ of height of the specimens were in direct contact with the water (Fig. 6).

The water absorption determined by mass variation. The specimens were weighted dry placed in water and weighted, after 5 minutes, 10 minutes, 15 minutes, 30 minutes, 1 hour, 2 hours, 4 hours, 6 hours and 8 hours.

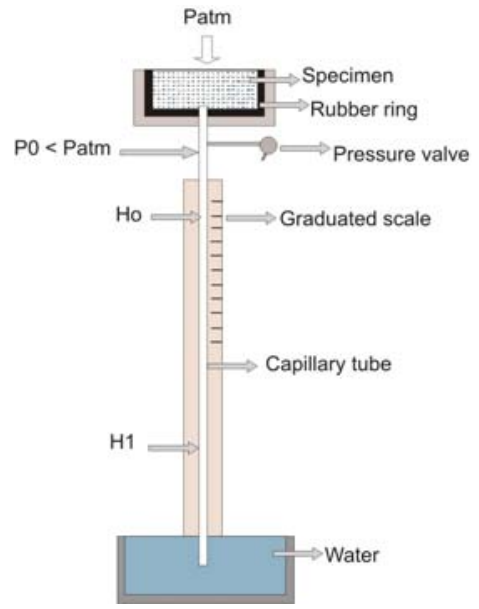

Fig. 5. Apparatus for air permeability test

\section{RESUlTS AND Discussions}

\section{A. Temperature Kinetics}

Recycled plaster (RP) was the mixture that presented higher temperature kinetics, reaching a maximum temperature of $57^{\circ} \mathrm{C}$. (Fig. 7)

The mixture GS-30 with $30 \%$ of red ceramic waste presented maximum temperature of $44{ }^{\circ} \mathrm{C}$.

The release of heat by the experimental mixtures in decreasing order was: GR, GS30, GSC60, GSC70, GS60 and GS70, showing that the bigger the quantity in mass of the plaster, higher will be the release of heat during the binder hydration, an expected result due to the presence of a higher binder quantity.

The presence of cement, though in small quantity $(5 \%)$, contributes to the increase of the temperature of the mortar (GSC60 and GSC70).

\section{B. Compressive Strength}

The results showed that, even by reducing the amount of recycled gypsum and increasing the amount of red ceramic, results of compressive strength reached values that meet the conditions for masonry hollow blocks according to the Brazilian standards (Fig. 8).

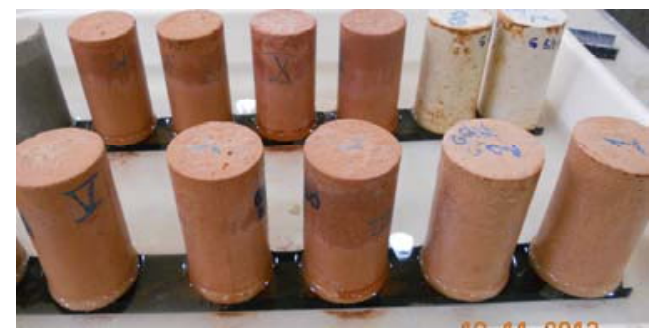

Fig. 6. Capillary water absorption test.

The mixture GS30had the best result (4.19 Mpa at 7 days and $4.49 \mathrm{MPa}$ at 28 days). And reaches the minimum value established by Brazilian standards for masonry hollow blocks (3.0 Mpa) [9]. The GSC70 mixture was the second mixture with a best result of compressive strength, even showing a higher amount of aggregate compared to mixtures GS60GSC60. However, GSC70 did not reach the minimum values required by the Brazilian standard [10].

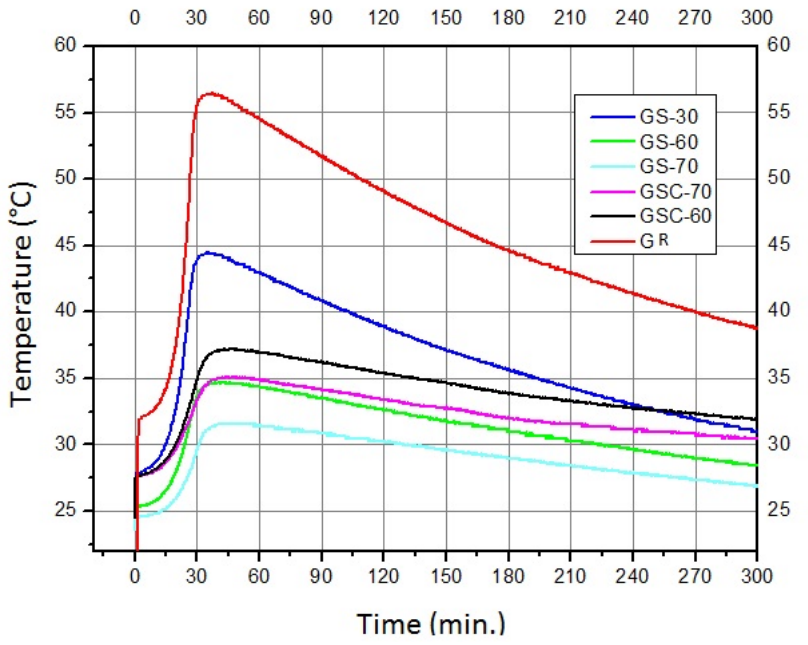

Fig. 7. Hydration kinetics of the mixtures used in the test.

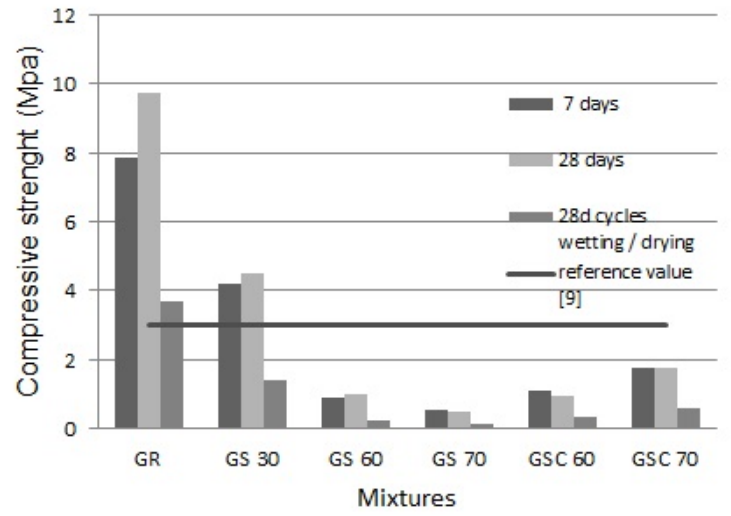

Fig. 8. Compressive strength results.

\section{Hardness Test}

The mixture GS30 had the best results in relation to the reference mixture (GR). At 28 days the best mixture had half of the value of the reference (GR) (Fig. 9).

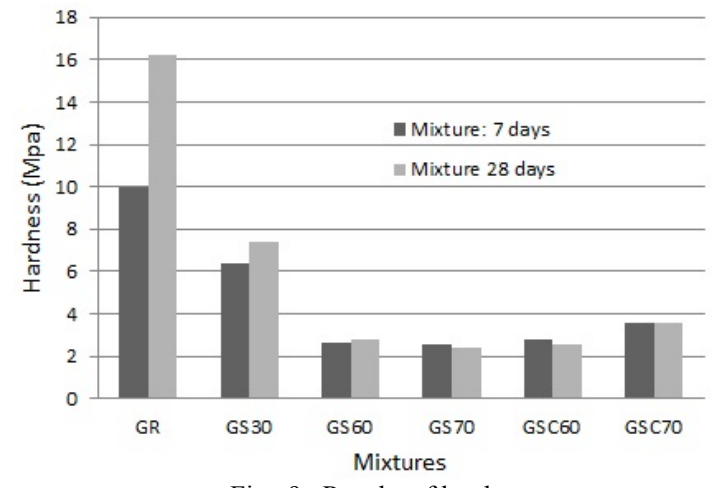

Fig. 9. Results of hardness test.

\section{Microstructure of the Mixtures}

Fig. 10 presents images of mixtures GR, GS30, GS60. Fig. 11 shows the images of mixtures, GS70 GSC60, GSC70. The 
mixture GR has a homogeneous distribution with some voids. GS30 mortar has a uniform distribution of red ceramic of different grain sizes. GS60 an increase of small grains of ceramic waste and well distributed in the matrix. The higher amount of red ceramic in the mortar modifies the color of the hardened mortar. Mortars with cement addition show a more compact matrix.
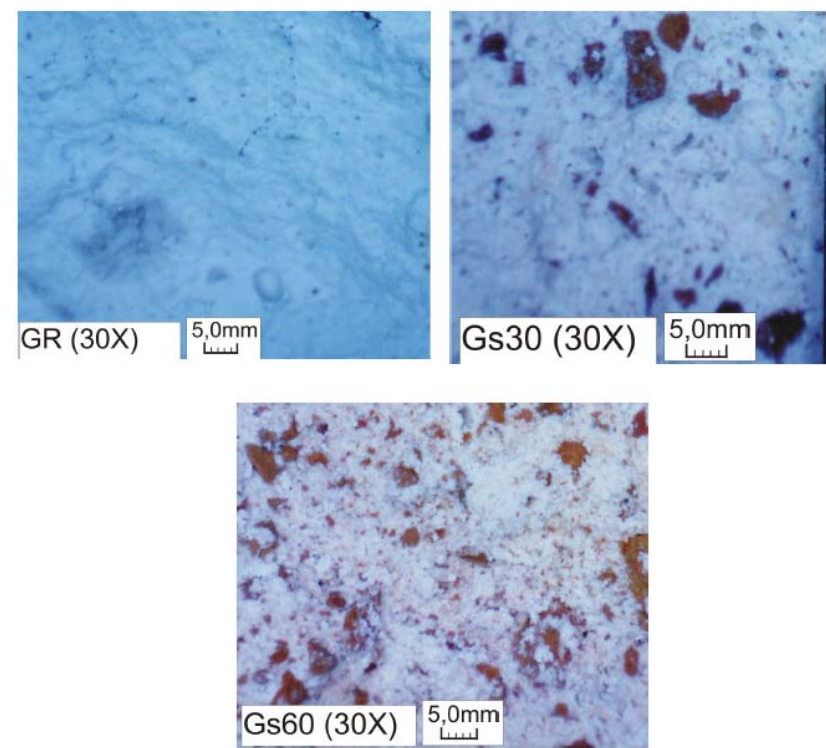

Fig. 10. Optical microscopy images of the mixtures GR, GS30 and GS60.

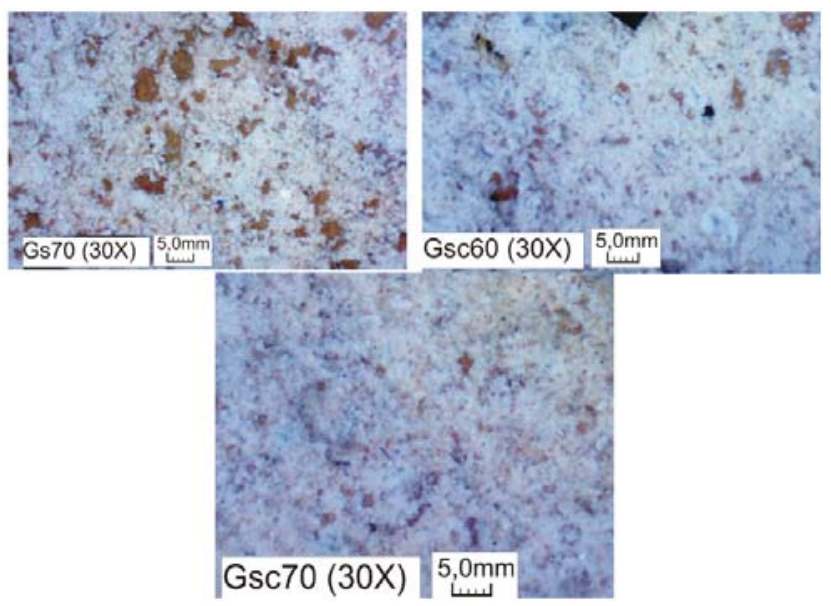

Fig. 11. Optical microscopy images of the mixtures GS70, GSC60 and GSC70.

It can also observe that the presence of voids (air bubbles) decreases as increases the amount of ceramic waste into the mix.

\section{E. Air Permeability Test}

Mixtures GS30, GS60 and GS70 obtained a reduction of their value of air permeability over time (Fig.12). Mixtures with cement addition (GSC60 and GSC70) were less permeable than the same mixture without cement. And their values increased between ages 7 and 28 days.

\section{F. Capillarity Test}

The mixture GS30 presented the best result of capillarity with a very close value to the reference mixture (GR), especially after an hour of testing, because the difference of capillarity between the two mixtures (GR and GS30) was around 4.0. kg/m² (Fig. 13). Mixture GSC60 accompanied the performance of the mixture GS30 until the 30 minutes of testing, then it began to absorb more water per $\mathrm{m}^{2}$, obtaining results very close to the values obtained from the mixture GS70, from 1 hour of the test until its completion. The GSC60 mixture was the second mixture with less increase in weight by water absorption per $\mathrm{m}^{2}$, with $48.85 \mathrm{~kg} / \mathrm{m}^{2}$ at the end of the experiment. Mixture GSC60 was following the same capillarity behavior of GS30, however, after 30minutes from the beginning of the test, GSC60 started to increase the values of capillarity, staying closer to mixtures GSC70 and GS70, even having a smaller quantity of ceramic waste.

Mixture GS70, despite being the one which more absorbed water up to 30minutes of testing, was the only paste that kept its weight, not absorbing more water from 2 hours of testing until its completion, with capillarity value of $49.10 \mathrm{~kg} / \mathrm{m}^{2}$. Similarly to the tests compressive strength and hardness, mixture GS30 obtained the best result of capillarity, following mixture GSC70.

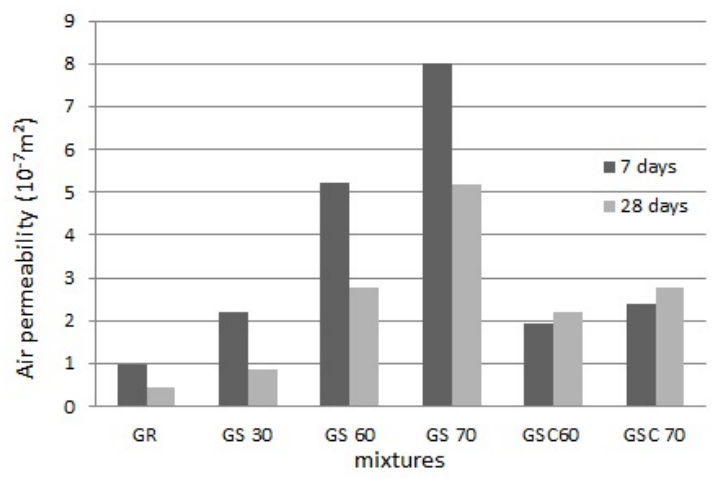

Fig. 12. Air permeability at 7 and 28 days.

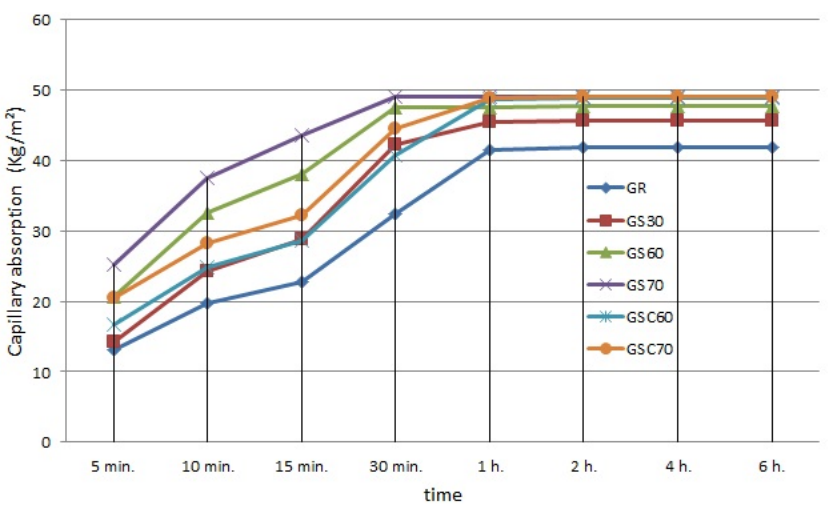

Fig. 13. Capillary water absorption results at 28 days in $\mathrm{kg} / \mathrm{m}^{2}$.

\section{CONCLUSIONS}

Data showed that the mixture with $30 \%$ of ceramic waste (GR30) had the best results in terms of compressive strength, hardness, permeability and capillarity in relation to the reference mixture (GR). In the compressive strength test, GR30 obtained values above the minimum required for sealing blocks, according to Brazilian standards. In the hardness test, it was the mixture that obtained a higher increase over time of around $1 \mathrm{Mpa}$. In the permeability test, at 28 days it obtained a considerable drop, staying closer to the results of the reference mixture (GR). In the capillarity test, it was also the mixture which got closer to the behavior 
of the reference mixture, especially after 1 hour from the beginning of the test.

Mixture GSC70, even with a bigger quantity of aggregate in relation to mixtures GS60 and GSC60 was the second mixture with better results in relation to compressive strength and hardness.

The objective of studying a mixture to mold sealing hollow blocks with good workability was achieved: mixture GS30 has good workability, presents a value of compressive strength that meets the minimum values required for that end according to the Brazilian standards.

Thus, the experimental study showed promising results in which recycled materials may become raw material for sealing blocks which meet the technical requirements, making it viable the adequate and responsible use of the CDW.

This way, it will be possible to produce elements and constructive materials with quality as well as they will be products that will carry environmental and economic responsibility by taking CDW from the environment and this way reducing the extraction of raw material.

The study allowed to prove real possibilities of realizing the use of CDW by civil construction and, therefore, putting into practice the new aspirations and responsibilities of the civil activity that most generates waste in the world.

\section{REFERENCES}

[1] T. F. Pacheco and J. A. Labrincha, "The future of construction materials research and seventh UM Milennium development Goal: a few insight tructionand," Construction and Building Materials, vol. 40, pp. 729-737, December 2012.

[2] V. M. John, S. C. Ângulo, and V. Agopyan, "Sobre a necessidade de metodologia de pesquisa e desenvolvimento para reciclagem," presented at the I Forum of Public Universities Paulistas - Science and Technology Waste, San Pedro, SP, Brazil, 2003.

[3] CONAMA. [Online]. Available: http://www.mma.gov.br/port/conama/legiabre.cfm?codlegi=307

[4] L. F. R. Miranda, Associação brasileira para reciclagem de resíduos da construção civil e demolição [Online]. Available: http://issuu.com/amandadiaspais/docs/pesquisa_setorial_abrecon_201 3 b645d5b7e 86212

[5] Instituto Brasileiro De Geografia E Estatística (IBGE). [Online], Available:

http://www.ibge.gov.br/home/estatistica/populacao/indicadores_sociai s municipais/tabela1a.shtm.

[6] S. C. Â. E. S. Cirelli, "Variabilidade de agregados GraúDOS de resíduos de construção e demolição reciclados," M.S. thesis, Dept. Eng., São Paulo State Univ, SP, Brazil, 2000.

[7] S. M. M. Pinheiro, "Gesso reciclado: avaliação de propriedades para uso em componentes," Ph.D. dissertation, Dept. Civil Eng. , Campinas State Univ.,Campinas, SP, 2011.

[8] G. C. Isaia, Materiais de Construção, 2 st ed. São Paulo, BR: IBRACON, 2010, ch. 18, pp. 565-566

[9] Blocos Cerâmicos: Terminologias E Requisitos, ABNT Standard 15270-1 -2005

[10] Gesso Para Construção - Determinação Das Propriedades fíSicas Do Pó, ABNT Standard, 1991.

[11] Red Ceramic Waste - Piacentini. (2013). [Online]. Available: http://www.popiacentini.com.br

[12] Gesso Para Construção-Determinação Das Propriedades Mecânicas ABNT Standard, 1991.

[13] V. Pereira and G. Camarini, "Air permeability of concrete by thenoz method," Green Building Technologies and Materials, Advanced Materials Research, vol. 224, pp. 132-136, April 2011.

[14] G. Camarini et al., "Methods to measure the transfer properties of mortars", Applied Mechanics and Materials, vol. 148-149, pp. 184-187, 2012.

[15] G. Camarini, "Curing effects on air permeability of concrete," Advanced Materials Research, vol. 214, pp. 602-606, 2011.

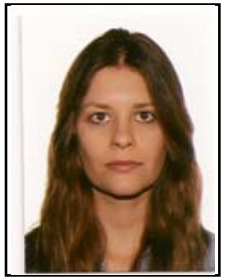

Brazil.
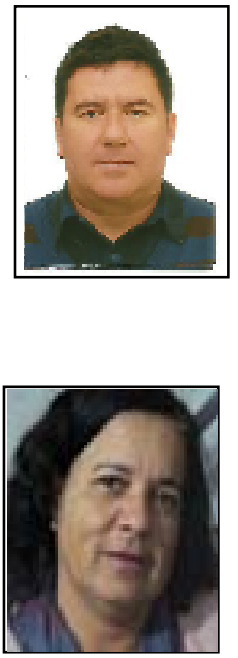

Paulo Cesar Domingues was graduated in civil engineering from the Federal University of Ouro Preto, MG, Brazil in 1985. In 1991 he obtained his master's degree by the São Carlos School of Engineering of the University of São Paulo, SP, Brazil. He is a professor at the Federal Institute of Education, Science and Technology of IFSuldeminas, MG, Brazil since 2012 and at the Pontifical Catholic University of Minas Gerais, Poços de Caldas, Mg, Brazil since 1999.

Brazil.

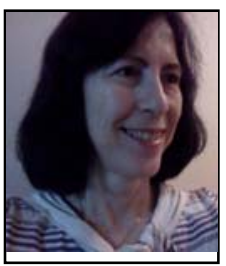

Gladis Camarini is a civil engineer and a professor at School of Civil Engineering, Architecture and Urban Design, University of Campinas. She had her master degree in 1988 and $\mathrm{PhD}$. degree in 1995 at University of São Paulo. She did postdoctoral studies at the Laboratoire des Materiaux et Durabilité des Constructions (LMDC) at Institut National des Sciences Apliquées (INSA, Toulouse, France, 1998). She also did postdoctoral studies at the National Institute for Space Research (INPE, São José dos Campos, Brazil, 2008). Then she also did postdoctoral studies at the Institute of Science and Technology del Hormigón (ICITECH), the Polytechnic School of Valencia (UPV) (Valencia, Spain, 2012). She is a peer-reviewer of scientific journals indexed on the Journal Citation Reports, national and international journals, Congress and Seminars, and Brazilian Research Foundations. She is an IACSIT senior member. Her research interests include building materials, mineral binders, mortars, industrial and construction wastes, reusing and recycling of materials, mortar, concrete, and other composites. 